Discussion Paper No. 15-069

\title{
The Impact of the Financial Crisis on Investments in Innovative Firms
}

Marek Giebel and Kornelius Kraft

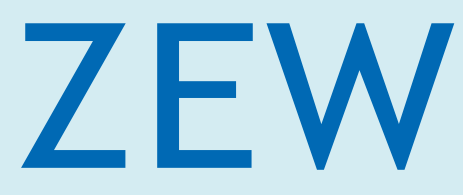

Zentrum für Europäische Wirtschaftsforschung $\mathrm{GmbH}$ Centre for European Economic Research 
Discussion Paper No. 15-069

\section{The Impact of the Financial Crisis on Investments in Innovative Firms}

Marek Giebel and Kornelius Kraft

Download this ZEW Discussion Paper from our ftp server:

http://ftp.zew.de/pub/zew-docs/dp/dp15069.pdf

Die Discussion Papers dienen einer möglichst schnellen Verbreitung von neueren Forschungsarbeiten des ZEW. Die Beiträge liegen in alleiniger Verantwortung der Autoren und stellen nicht notwendigerweise die Meinung des ZEW dar.

Discussion Papers are intended to make results of ZEW research promptly available to other economists in order to encourage discussion and suggestions for revisions. The authors are solely responsible for the contents which do not necessarily represent the opinion of the ZEW. 


\title{
The impact of the financial crisis on investments in innovative firms*
}

\author{
Marek Giebel $^{\text {a }} \quad$ Kornelius Kraft $^{\mathrm{b}}$
}

September 2015

\begin{abstract}
This paper investigates the impact of the financial crisis on investment decisions in innovative versus non-innovative firms. Firms are defined as being innovative if they have introduced a new product to the market. The empirical test is based on data for the years before and after the recent financial crisis. Probit estimations show that innovative firms are more likely to suffer from the financial crisis and to reduce their investment expenditures in general. To some extent these reductions are due to problems in the acquisition of external capital. Using difference-in-differences methods, it turns out that innovative firms realize the same reduction in growth rates in turnover, but a stronger reduction in investment growth than non-innovative firms.
\end{abstract}

Keywords: Financial crisis, innovation, investment, credit constraints, difference-in-differences

JEL Classification: G01, G30, O16, O30

*We gratefully acknowledge financial support by the Deutsche Forschungsgemeinschaft (DFG) grant KR 929/7-1.

\footnotetext{
${ }^{\mathrm{a}}$ TU Dortmund, Faculty of Business, Economics and Social Sciences, Vogelpothsweg 87, D-44227 Dortmund, Marek.Giebel@tu-dortmund.de

b TU Dortmund, Faculty of Business, Economics and Social Sciences, Vogelpothsweg 87, D-44227 Dortmund, ZEW Mannheim and IZA Bonn, Kornelius.Kraft@tu-dortmund.de
} 


\section{Introduction}

It is generally acknowledged that innovations are of major importance for the growth of an economy. Innovations increase consumer surplus through the introduction of new products, improved quality of existing products and price reductions due to process innovations. On the microeconomic level firms have incentives to pursue innovative activity to obtain an advantage over rivals, enter new markets and to achieve a (temporary) monopoly position.

At least since the contributions of Schumpeter it is well known that the financing of innovations is a complex issue. Obviously innovative activity is risky and the risk increases with the degree of novelty to the market. This risk exists due to major uncertainties with respect to the success of their R\&D process and market acceptance of their product. Moreover a major problem exists with respect to asymmetric information between innovator and banks as money lenders. This leads to severe difficulties for innovative firms to get access to external financing (Hall 2002). Especially those firms which intend to introduce a novelty to the market encounter serious constraints with respect to external finance (Czarnitzki and Hottenrott 2011a).

The financial crisis is often associated with the collapse of Lehman Brothers in 2008. Although the problems began earlier, this event became the major trigger for the turmoil on the financial markets. It is well known that the financial crisis led to serious problems for the banks, many of whom lost money so that these resources were no longer available as credit for the private sector. Furthermore, regulations concerning equity, improved risk control and improved disclosure affected credit management. With some likelihood, the blight suffered by the financial sector was also transmitted to the real economy. With a shortage of capital, banks become more selective about the financing of projects, and it is quite probable that risky activities like innovation suffer as a result.

The aim of the present study is an analysis of whether investment in innovative firms in particular was affected by the consequences of the financial crisis. Innovative activity is by its very nature risky, and it may well be that innovative firms in general have greater difficulty accessing external finance. However, this difficulty might have been intensified during the financial crisis and may then have affected investment, a largely externally financed activity. We investigate whether innovative firms report increased obstacles to financing investment from external 
sources and whether these firms encountered more substantial reductions in investment than noninnovators.

In our study innovation is specified by the introduction of a product new to the market. ${ }^{1}$ In the first part of our analysis we use survey data to test on differences between innovative and noninnovative firms on changes in investment behavior. We analyze whether reductions in investment due to the crisis are more likely for innovative firms. Moreover, the survey that we use also includes explicit information on whether innovative firms are more likely to reduce their investments in the crisis due to a lack of access to external funds.

The second part of our study considers effects on revenues and investment. The change (reduction) in revenues identifies the development of demand and availability of internal means during the crisis. Next investment is considered. It is of general interest to investigate how investment evolves in times of economic crisis and whether there are differences between innovators and non-innovators. What is more, investment is an activity that is largely financed externally and it is possible that innovators and non-innovators had different chances to get access to external finance during the crisis. Hence we investigate whether revenues and investment changed similarly for both firm types, or whether investment growth differs from sales growth and between innovators and non-innovators.

The empirical analysis is based on data from the IAB establishment panel and includes the waves 2006 to 2010. The IAB establishment panel $^{2}$ samples about 16,000 firms and covers several establishment characteristics and questions related to innovation and investments. The panel character allows us to compare changes in outcome, such as investments and revenues, for innovative firms with others.

We contribute to a strand of literature which investigates the impact of the financial crisis on innovative firms. Our approach is the combination of two types of test. Firstly, we use questionnaire-based assessments of the crisis' impact on firms ${ }^{3}$. Among other issues the survey that we use inquires about the impact of the crisis, modification of investment plans in 2009,

\footnotetext{
${ }^{1}$ cf. Lee at al. (2015) for a similar procedure. Czarnitzki and Hottenrott (2011a) show that financing constraints are more binding for innovators introducing a novelty to the market (cutting edge R\&D performers) by comparing them with firms that either imitate or improve products (routine R\&D performers).

${ }^{2}$ The data was collected by the Institute for Employment Research (IAB), located in Nuremberg, Germany.

${ }^{3}$ Related research was done by Campello et al. (2010) and Paunov (2012).
} 
whether these modifications were the result of the financial crisis and, finally, whether the changes in investment were due to problems in accessing external capital. Hence, the survey allows us to investigate for the first time in detail the relation between the crisis, the effect on investment in general and in particular the impact of problems in accessing external financial sources on investment expenditures for innovative firms. Secondly, we employ a difference-indifferences setting to investigate the impact of the financial crisis on innovative firms with respect to revenues and investments. To our knowledge, this is the first study which combines both approaches to analyze whether innovators' investment plans are affected more by the crisis than others.

Our results show that innovative firms more frequently report reduced investments due to the financial crisis. Moreover, according to the survey questions innovators were likelier to cut investment due to the problem of obtaining external capital. Secondly, aside of the responses to qualitative questions in the survey, difference-in-differences estimations with economically relevant variables are carried out. The results show that, compared with control observations, innovators did not realize less revenue growth. However, according to the difference-indifferences results, innovative firms realized lower investment growth due to the crisis. Hence, these results point to the conclusion that innovative firms have suffered much more from the financial crisis than non-innovative firms.

\section{The impact of the crisis on innovative firms' access to external finance and investment}

\section{II.1 Theoretical considerations of the problems of innovative firms to finance R\&D and investment in conventional assets}

The specific situation related to financing $R \& D$ has been a subject of discussion for some time now. In principle there are two sources for financing investment in $R \& D$ for innovative firms: internal or external. Internally generated sources mainly consist of cash flow. External sources on the other hand tend to take the form of bank loans or other similar debt-oriented lending relationships (David et al. 2000). As pointed out by Myers and Majluf (1984) firms prefer to finance their investment activities by internal means. When internal resources are limited, firms are interested in external financing before turning to equity as a source of finance. 
Investment in innovation is different from investment in conventional assets. According to Hall (2002) there are three main differences between R\&D and other investments. Firstly, expenditure for R\&D is used to create intangible assets which are the basis for future profits. These assets are intangible because a large part of the expenditure goes toward employing highly educated staff and is therefore investment in human capital. Therefore, a major part of the investment is sunk. Secondly, investment in R\&D cannot be used as collateral value as it would be the case with a normal investment. Thirdly, obviously there is a high degree of uncertainty connected with innovation activities. To be profitable R\&D must lead to an innovation and this innovation must then be successful at the market. In most cases financing of innovation also implies problems arising from asymmetric information. The inventor usually has better information about the probability of success of the R\&D project and the market value of the innovation. These specific circumstances lead to higher interest rates for external funds or to the unavailability of this kind of financing at all.

Aside of leading to problems in financing their R\&D expenditures by external sources, innovative activity may well have implications for financing other projects like investment. As stated earlier, innovation is a risky activity and innovative firms may face higher business risks in general. New investment is frequently undertaken to install new process innovation or to generate capacities for product innovations. As investment may be a consequence of innovation activity such firms may also realize larger problems with financing investment than non-innovators. Financial constraints for investment in particular have been a topic of discussion for some time. ${ }^{4}$ Investment expenditures are perhaps less risky than expenditures for innovation, as tangible assets are created, but they remain risky to some degree. Risk is higher for investment connected with new products and processes, and the asymmetric information problem is here also an issue.

\section{II.2 Empirical Evidence concerning the financing of investment and R\&D}

A growing amount of literature on innovation discusses financing constraints for innovative firms. With respect to the kind of innovation, there is evidence to suggest that innovative firms which introduce novelties to the market face more binding constraints than imitators (Czarnitzki and Hottenrott (2011a)). Likewise, Mina et al. (2013) point out that innovative firms might encounter greater problems regarding access to external finance.

\footnotetext{
${ }^{4}$ Early theoretical works concerning imperfect information, credit rationing and investments are for example Stiglitz and Weiss (1981) as well as Holmstrom and Tirole (1997).
} 
In addition to studies which concentrate solely on innovation ${ }^{5}$ or investments ${ }^{6}$ there are studies which focus on investment in both physical assets and R\&D. Hall (1992) finds that liquidity matters for investment in both physical assets and R\&D, using cash flow as an indicator for the availability of internal means. If internal sources have such a large relevance, this is an indicator of the existence of financial constraints. Moreover, further evidence exists for innovative firms that financing constraints matter for both $R \& D$ and ordinary investments (Himmelberg and Petersen (1994), Harhoff (1988) and Czarnitzki and Hottenrott (2011b)).

\section{II.3 The impact of the financial crisis on lending behavior of banks}

The collapse of Lehman Brothers in late 2008 marks one of the most important events during the recent financial crisis. The crisis impacted on banks firstly if they relied on the interbanking market and secondly if they themselves had risky assets in their portfolio that dramatically lost in value. Such unfortunate circumstances reduced the banks' resources for lending. Aside of these reasons for increased obstacles to debt financing, during and after the crisis banks implemented a stricter risk management. This was induced by external requirements of the Basel II accord, but was also the consequence of tightened risk assessment by banks to avoid losses from defaults after the lessons learned from the crisis.

In addition to theoretical investigations ${ }^{7}$, empirical studies present evidence that lending activities were indeed reduced because of the crisis (Ivashina and Scharfstein 2010, Puri et al. 2011). Besides the impact on the banking sector, the financial crisis had an impact on the demand from firms for credit and access to credit. Taking a sample of UK firms, Cowling et al. (2012) present evidence that a larger firm size and a decrease in sales are important drivers of higher demand for external means. Moreover, they show that small firms suffer more than larger firms from impeded access to external capital by banks. With respect to the source of capital of the banks themselves, Iyer et al. (2014) show that the breakdown of the interbanking market led to a reduction of firm credit by banks which relied heavily on this source to finance lending activities.

\footnotetext{
${ }^{5}$ Bond et al. (2005) for example takes cash flow as one of the most common measures reflecting internal means and as an indicator for constraints. A direct way of analyzing the financing constraints of innovative firms using survey data on delayed or abandoned innovation projects due to problems accessing external finance is undertaken by Mohnen et al. (2008), Tiwari et al. (2007) and Savignac (2008).

${ }^{6}$ The studies by Fazzari et al. (1988) and Whited (1992) for example point to the conclusion that some firms have difficulties financing investment externally.

${ }^{7}$ The theoretical investigation by Brei and Schclarek (2015) shows that lending by publicly and privately owned banks is reduced during the crisis.
} 


\section{II.4 The impact of the financial crisis on expenditures for $R \& D$ and investment}

Besides the impact of the financial crisis on banks, which made accessing external capital more difficult for firms in general, these problems are particularly prevalent for innovative firms. A recent paper by Lee et al. (2015) shows that all firms (innovators and non-innovators) face problems accessing external financing. Secondly, Lee et al. (2015) illustrates that a higher share of innovators apply for external finance than non-innovators. Moreover, they face more difficulties accessing finance.

In the literature two possible effects of the recent crisis on R\&D expenditures for innovative firms are suggested. On the one hand firms might increase their R\&D spending in the crisis to possibly enter new markets or launch new products (Archibugi et al. (2013a, 2013b). On the other hand the problems accessing external finance limit the resources for financing R\&D and this is also observed during the recent financial crisis (Filipetti and Archibugi 2011, Kipar 2011, Paunov 2012). ${ }^{8}$ Furthermore, empirical evidence points to a reduction in investment behavior due to financial constraints in the crisis (Campello et al. (2010), Duchin et al. (2010)). ${ }^{9}$

\section{II.5 Hypotheses}

Risk in general will be of higher relevance for innovative firms, as investment frequently aims at producing newly developed products, as well as the fact that success at market is quite uncertain. Investment also serves the purpose of realizing process innovations and, aside of lower marginal costs, a new technology will imply technological risks and high fixed costs. If banks must limit their lending, they may well reduce the supply of capital to finance the investment of innovative firms. Our particular research question is the impact of the crisis on the investment behavior of innovative firms. In this regard the theoretical considerations and the empirical results lead us to the following hypothesis:

\footnotetext{
${ }^{8}$ Filippetti and Archibugi (2011) find that larger and more R\&D-intensive firms likelier reduced their innovation investments because of the crisis. Paunov (2012) shows that innovative projects are more frequently stopped due to the crisis by young firms. Public funding instead leads to a reduction in the likelihood of discontinuing an innovation project. Based on the hypothesis that cooperative banking institutions did not suffer from the financial crisis, Kipar (2011) finds that business partners from such banks report less frequently of credit constraints and stop fewer ongoing innovation projects.

${ }^{9}$ Comparing constrained and unconstrained firms, Campello et al. (2010) present empirical evidence that constrained firms are more likely to reduce investments and technology expenditures because of the crisis. Duchin et al. (2010) shows that investments decline due to the crisis. They find in particular, that firms are hit the most if they have either low cash reserves, are financially constrained or have their main field of operation in industries which rely heavily on external financing.
} 
Hypothesis 1: Compared with non-innovators, product-innovative firms are more likely to suffer from worsening financial market conditions with respect to access to finance in the recent crisis. In consequence, innovative firms are more likely to react with a reduction in investment.

This hypothesis will be tested by means of data from a questionnaire. This allows us to determine the likelihood of a reduction in investment for innovative firms. Aside of analyzing the development of investment in general we also investigate whether the change is due to increased problems accessing external finance.

The second hypothesis aims at a test based on firm data. Here information on changes in sales over time is compared with changes in investment. Revenues are considered in order to take account of the development of the economic environment. Investment by innovators might decline more strongly than investment by non-innovators, even if the business conditions in terms of demand (reduction) are comparable to the external and internal conditions of non-innovators. This leads us to our second research hypothesis:

Hypothesis 2: Both innovative and non-innovative firms are likely to face a similar fall in demand. This will probably lead to an increased need for external financing for both firm types. Despite a similar reduction in sales, productive innovative firms reduce investment to a larger extent than their non-product innovative counterparts.

\section{Data}

This study uses the IAB Establishment Panel, waves 2006 -2010. Data access was provided via remote data access. The IAB Establishment Panel covers about 16,000 firms, which are surveyed yearly. The IAB panel has been collecting observations from West German establishments since 1993 and East German ones since 1996. The main emphasis of the panel is on labor demand and firm-specific determinants of employment. However, in addition to these topics other interesting information on innovation and investment is also collected. On an irregular basis special questions are added to the survey that focus, for example, on the financial crisis and its effects on these firms. 


\section{Test for limited access to financing means due to the crisis}

To test the hypotheses stated above, we need to identify the innovative firms first. Hypothesis 1 requires us to test whether these firms are more frequently affected by the financial crisis. Furthermore, we have to determine whether these firms have greater problems accessing external finance. To do so, it is necessary to construct variables that reflect the impact of the financial crisis on firms. For a test of hypothesis 2, we must separately identify the development of revenues and investment over time for innovative and non-innovative firms.

\section{IV.1 Identification of innovative firms}

Innovativeness is defined as the introduction of a product new to the market (not just new to the firm). Such firms are likely to bear considerable risk and to be affected by financial constraints as a result. For identification we use the following question from 2007: "Have you started to offer a completely new product or service within the last two years for which a new market had to be created?" with the possible answers: "Yes" and "No". From this question we are able to construct a variable Innovator which takes unit value if the firm introduced a product innovation in the years 2005 or 2006 and zero if not. We use this question from 2007 because the covered years 2005 and 2006 were the last ones before the crisis broke.

We control for differences in industries with respect to innovation activity and sales by using industry dummies. We deal with the issue that the firms could have carried out a service innovation instead of a product innovation by only using observations from the manufacturing sector.

\section{IV.2 Financial crisis and financing restrictions}

As mentioned earlier, we use two strategies to identify the impact of the financial crisis on innovative firms: analysis of survey data and difference-in-differences estimations based on economic data. With respect to direct information from the survey 2010 concerning the impact of the crisis, the firms were firstly asked whether they are affected by the crisis at all: "In retrospect: did the economic and financial crisis of the past two years affect your establishment/office? This question refers to both negative and positive effects." with the following options: "Yes”, "No", or "Hard to say". The constructed variable Affected by the crisis assumes value one if the firm was impacted by the crisis and zero if not. In a second step the firms which were affected by the 
crisis were asked how they were affected: "Were the effects on your establishment/office mainly negative, mainly positive or both equally?” We create a variable Negatively affected by the crisis from both questions which takes unit value if the firm was impacted mainly negatively by the crisis.

Next, we analyze the impact of the crisis on financing. First, the firms were asked whether they modified their investment plans: "Did you modify your investment plans in the fiscal year 2009 compared to the original plans? Or were no investments intended anyway?” This question is the basis for the upcoming questions concerning the crisis and the financing of investments. Second, it is possible to investigate whether the changes in investment plans are due to the financial crisis: "Were these modifications made as a result of the financial and economic crisis?” with "Yes" and "No" as possible answers. Firms which answered with "Yes" were probably hit by the crisis but up to this point it is unclear in which way the firms changed their plans.

Furthermore, we are able to use information on changes to investment planning by including a third question: "Which modifications were made?" The options for answering were "We put planned investments on hold or reduced them", "We increased the investment volume” or "Other modifications". The variable Investment reduced due to the crisis is specified which takes the value 1 if the firm modified the investment plans due to the crisis and the modification was a reduction to investments.

Finally, those firms which reduced their investments could state whether this change was caused by problems in accessing external capital: "Did you have to overcome difficulties in acquiring loan capital from private credit institutions resulting in a deferment or reduction of the planned investments?". The possible answers are simply "Yes" and "No". The answer "Yes" is a clear indicator for problems in accessing external finance. Thus, the question directly aims at the impact of the financial crisis on the firms. Due to the direct measure it is possible to identify firms which suffered from problems accessing external finance directly and as a consequence were forced to reduce investments. The variable Investment reduced due to the crisis and therein problems in accessing external capital assumes unit value if the firm replied in the affirmative. 


\section{IV.3 Estimation strategy to identify financing restrictions for innovative firms}

We use Probit regressions to test hypothesis 1 . In particular, we test whether innovative firms are more often impacted by the crisis and furthermore how. Moreover, we are able to control for other factors which could determine the results besides of being innovative or not.

The first specification allows testing whether generally innovative firms are affected by the financial crisis to a larger degree and whether they are affected negatively. The specification is as follows:

$$
A_{i}=\beta_{0}+\beta_{1} * \text { Innovator }_{i}+\gamma * X_{i}+\text { Industry }_{i}+\varepsilon_{i}
$$

Where $A_{i}$ covers the outcomes for being affected as described above and is Affected in one specification and AffectedNegatively in the other. $X_{i}$ covers the following variables: Founded $97-07_{i}$ is a dummy variable which assumes unit value if a firm was founded between 1997 and 2007 and is otherwise zero. Younger firms are assumed to have greater problems with respect to financing than older firms. The variable $\ln (\operatorname{Size})_{i}$ is the logarithmic value of employment of firm $i$ and controls for size effects. It is to be expected that larger firms are affected less by the crisis and have fewer problems with access to external financing. The variable $\ln (\text { Size })_{i}^{2}$ additionally controls for a non-linear relationship with respect to the logarithmic value of a firm's employment. We control for possible effects of a firm's location in the eastern and western parts of Germany. Different effects could arise from the subsidization of firms in eastern Germany. To do so, we include the dummy variable EastGermany E $_{i}$ which assumes unit value in the case of firms which are located in the eastern part of Germany and zero otherwise. To take account of participation in international trade we include a dummy ActiveExporter $_{i}$ which takes unit value if the firm exports goods and zero otherwise. To control for differences across industries we include a set of industry dummies Industry . $_{\text {. }}$

A second specification tests whether there are significant differences between treated firms and control observations with respect to changes to investment plans. These alterations in turn may be caused by the financial crisis and because of problems in acquiring external financing. The question was asked in both questionnaires 2009 and 2010 and therefore we use a pooled Probit regression for the two years, including a time dummy and an interaction variable. The specification looks like this: 


$$
\begin{aligned}
I_{i} & =\beta_{0}+\beta_{1} * \text { Innovator }_{i} \times 2009_{i}+\beta_{2} * \text { Non }- \text { Innovator }_{i} \times 2010_{i} \\
& +\beta_{3} * \text { Innovator }_{i} \times 2010_{i}+\gamma * X_{i}+\text { Industry }_{i}+\varepsilon_{i}
\end{aligned}
$$

Where $I_{i}$ covers the outcomes concerning the way establishments were affected with respect to investments constructed above: Investment reduced due to the crisis and Investment reduced due to the crisis and problems in accessing external capital. Since the question was asked in two years, we include the interaction variables Innovator $_{i} \times 2009_{i}$, Non - Innovator ${ }_{i} \times 2010_{i}$ and Innovator $_{i} \times 2010_{i}$ to cover the reactions of the noninnovative and innovative firms in both years 2009 and 2010. The reference category is noninnovative firms in 2009. Innovator ${ }_{i} \times 2009_{i}$ captures investment reactions of innovative firms concerning investments in the year 2009 in comparison to non-innovative firms in 2009. The two interaction variables covering the behavior of non-innovative and innovative firms in 2010 are Non - Innovator ${ }_{i} \times 2010_{i}$ and Innovator $_{i} \times 2010_{i}$. This procedure is applied to identify time-specific differences with respect to innovative and non-innovative firms. Moreover, the specification determines whether the effect of the crisis on investments was the same in 2009 and 2010, or alternatively tests whether the crisis abated or was over in 2010.

\section{IV.4 Probit regression results}

Descriptive statistics for the variables described above are given in Table 1 for innovators and non-innovators. Innovators compared to non-innovators are on average more often negatively affected by the crisis. Moreover, they more often report reduced investments due to the crisis and limited access to external financing in the crisis. 
Table 1: Descriptive statistics for innovators and non-innovators

\begin{tabular}{|c|c|c|c|c|c|c|c|c|c|c|}
\hline \multirow{2}{*}{ Variable } & \multicolumn{5}{|c|}{ Innovators } & \multicolumn{5}{|c|}{ Non-Innovators } \\
\hline & $\mathrm{N}$ & Mean & SD & Min & Max & $\mathrm{N}$ & Mean & SD & Min & Max \\
\hline Affected by the crisis & 483 & 0.781 & 0.414 & 0 & 1 & 1736 & 0.670 & 0.470 & 0 & 1 \\
\hline $\begin{array}{l}\text { Negatively affected by the } \\
\text { crisis }\end{array}$ & 458 & 0.769 & 0.422 & 0 & 1 & 1649 & 0.653 & 0.476 & 0 & 1 \\
\hline $\begin{array}{l}\text { Investment reduction due to } \\
\text { the crisis }\end{array}$ & 351 & 0.835 & 0.372 & 0 & 1 & 837 & 0.778 & 0.416 & 0 & 1 \\
\hline $\begin{array}{l}\text { Investment reduction due to } \\
\text { the crisis and therein } \\
\text { problems in accessing } \\
\text { external finance }\end{array}$ & 107 & 0.458 & 0.501 & 0 & 1 & 303 & 0.386 & 0.488 & 0 & 1 \\
\hline $\begin{array}{l}\text { Founded between } 1997 \text { and } \\
\quad 2007\end{array}$ & 697 & 0.113 & 0.317 & 0 & 1 & 2247 & 0.149 & 0.356 & 0 & 1 \\
\hline Size & 697 & 827.311 & 4129.997 & 2 & 49221 & 2247 & 192.472 & 635.700 & & 15091 \\
\hline Located in eastern Germany & 697 & 0.463 & 0.499 & 0 & 1 & 2247 & 0.511 & 0.500 & 0 & 1 \\
\hline Active exporter & 697 & 0.782 & 0.413 & 0 & 1 & 2247 & 0.523 & 0.500 & 0 & 1 \\
\hline
\end{tabular}

Results for the Probit regressions are given in Table $2 .^{10}$ The results presented in column (1) show that the coefficient of the variable Innovator is significant and positive. This suggests that innovative firms are more severely affected by the crisis than others. If geographical location and exporting behavior (columns (2) and (3)) are controlled for, the effect remains significant. Firms located in the eastern part of Germany suffer less from the crisis. In contrast, exporting increases the likelihood of being hit by the crisis. Apparently exporting does not "insure" firms against the consequences of the financial crisis: on the contrary, the multi-market contacts intensify them.

In the next step the direction of the impact of the crisis is investigated. Columns (4) to (6) show that Innovator is positive and significant at the 5 percent level. Therefore, as expected, innovative firms are negatively affected by the crisis. Being located in eastern Germany and the logarithm of the variable size have similar effects as in columns (2) and (3). The coefficient showing the effect of being located in eastern Germany is now significant at least at the 5 percent level. Moreover, the results for the remaining control variables are close to the ones reported in columns (1) to (3).

\footnotetext{
${ }^{10}$ Marginal effects are calculated following the suggestion made by Puhani (2012) for non-linear models.
} 
Table 2: Estimation results for the variables describing impact by the crisis

\begin{tabular}{|c|c|c|c|c|c|c|}
\hline \multirow{2}{*}{ Variable } & \multicolumn{3}{|c|}{ Affected by the crisis } & \multicolumn{3}{|c|}{ Negatively affected by the crisis } \\
\hline & (1) & (2) & (3) & (4) & $(5)$ & $(6)$ \\
\hline Innovator & $\begin{array}{l}0.050^{* *} \\
(0.022)\end{array}$ & $\begin{array}{l}0.052^{* *} \\
(0.022)\end{array}$ & $\begin{array}{l}0.044^{* *} \\
(0.022)\end{array}$ & $\begin{array}{l}0.054^{* *} \\
(0.023)\end{array}$ & $\begin{array}{l}0.056^{* *} \\
(0.023)\end{array}$ & $\begin{array}{l}0.048^{* *} \\
(0.023)\end{array}$ \\
\hline $\begin{array}{l}\text { Founded between } 1997 \text { and } \\
2007\end{array}$ & $\begin{array}{r}-0.022 \\
(0.030)\end{array}$ & $\begin{array}{r}-0.021 \\
(0.030)\end{array}$ & $\begin{array}{r}-0.023 \\
(0.030)\end{array}$ & $\begin{array}{r}-0.032 \\
(0.034)\end{array}$ & $\begin{array}{r}-0.031 \\
(0.034)\end{array}$ & $\begin{array}{r}-0.033 \\
(0.033)\end{array}$ \\
\hline $\ln ($ Size $)$ & $\begin{array}{l}0.064 * * * \\
(0.015)\end{array}$ & $\begin{array}{l}0.064^{* * *} \\
(0.015)\end{array}$ & $\begin{array}{l}0.039 * * * \\
(0.014)\end{array}$ & $\begin{array}{l}0.064^{* * *} \\
(0.015)\end{array}$ & $\begin{array}{l}0.064^{* * *} \\
(0.016)\end{array}$ & $\begin{array}{l}0.039 * * * \\
(0.014)\end{array}$ \\
\hline $\ln (\text { Size })^{2}$ & $\begin{array}{l}-0.003 * \\
(0.001)\end{array}$ & $\begin{array}{l}-0.003^{* *} \\
(0.001)\end{array}$ & $\begin{array}{l}-0.002 \\
(0.001)\end{array}$ & $\begin{array}{l}-0.003^{*} \\
(0.002)\end{array}$ & $\begin{array}{l}-0.003^{* *} \\
(0.002)\end{array}$ & $\begin{array}{r}-0.002 \\
(0.001)\end{array}$ \\
\hline Located in eastern Germany & & $\begin{array}{l}-0.029 * * \\
(0.013)\end{array}$ & $\begin{array}{l}-0.024^{*} \\
(0.013)\end{array}$ & & $\begin{array}{l}-0.033^{* * *} \\
(0.013)\end{array}$ & $\begin{array}{l}-0.028^{* *} \\
(0.013)\end{array}$ \\
\hline Active exporter & & & $\begin{array}{l}0.116^{* * *} \\
(0.024)\end{array}$ & & & $\begin{array}{l}0.113^{* * *} \\
(0.024)\end{array}$ \\
\hline Industry Dummies & Yes & Yes & Yes & Yes & Yes & Yes \\
\hline $\mathrm{N}$ & 2219 & 2219 & 2219 & 2107 & 2107 & 2107 \\
\hline Pseudo- $R^{2}$ & 0.100 & 0.101 & 0.110 & 0.103 & 0.105 & 0.113 \\
\hline
\end{tabular}

Cluster-robust standard errors in parentheses. Clustered at the industry level. ${ }^{*}$ significant at the $10 \%$ level, $* *$ significant at the $5 \%$ level, *** significant at the $1 \%$ level.

A more detailed picture with respect to the influence of the crisis is given by the results presented in Table $3{ }^{11}$ The first and second columns show the basic results for the outcome variable Investment reduced due to the crisis. This variable takes unit value if the firms changed their investment plans by reducing their investment due to the crisis and zero if no change took place. Firstly, the interaction Innovator $\times 2009$ indicating innovative firms in 2009 is positive and significant. This implies that these firms, compared to non-innovative firms in 2009, are more likely to be affected by the crisis and reduce their investments. Similarly to most of the literature, we observe effects for young firms and size, but in our case they are not significant (except the coefficient of $\ln (S I Z E)^{2}$ in columns (1) to (3)). Controlling for geographical location and exporting behavior does not alter the size of the coefficient of Innovator $\times 2009$ much and it remains significant. The interaction Non - Innovator $\times 2010$ is negative and significant at the 1 percent level, which expresses that the reduction due to the crisis is less pronounced in 2010 compared to 2009 for the non-innovative firms. Additionally, the interaction term Innovator $\times 2010$ is also negative (and significant). This indicates that the innovative firms less frequently report investment reductions due to the crisis in 2010 compared to non-innovative firms in 2009.

\footnotetext{
${ }^{11}$ Marginal effects are calculated following the suggestion made by Puhani (2012) for non-linear models. 
In columns (4) to (6), the results reflect the presence of problems in accessing external finance which led to reductions in investment in the crisis. Again, the coefficient for Innovator $\times 2009$ is positive and significant at least at the 10 percent level. Hence, the innovative firms are affected more frequently by problems with respect to external capital and therefore reduce their investments compared to the non-innovators in 2009. Size coefficients in column (4) show the expected signs. Again, in columns (4) to (6), the interactions Innovator $\times 2010$ and NonInnovator $\times 2010$ are negative and significant. This shows that product-innovative firms are less likely to report that they reduced their investments due to problems in acquiring external capital in the crisis in 2010 compared to 2009. Moreover the non-innovators are less likely to reduce their investments because of problems in acquiring external capital in 2010 compared to 2009.

Summing up we observe that the innovative firms are more likely to be affected by the crisis in general and that this impact is a negative one. Taking a closer look at the effects it turns out that the innovative firms reduced their investments. Moreover, the reduction in investments appears to be caused by problems accessing external finance. 
Table 3: Estimation results for the investment behavior

\begin{tabular}{|c|c|c|c|c|c|c|}
\hline \multirow[t]{2}{*}{ Variable } & \multicolumn{3}{|c|}{ Investment reduction due to the crisis } & \multicolumn{3}{|c|}{$\begin{array}{l}\text { Investment reduction due to the crisis } \\
\text { and therein problems in accessing } \\
\text { external finance }\end{array}$} \\
\hline & (1) & (2) & (3) & (4) & (5) & (6) \\
\hline Innovator $\times 2009$ & $\begin{array}{l}0.091 * * \\
(0.036)\end{array}$ & $\begin{array}{l}0.090 * * \\
(0.036)\end{array}$ & $\begin{array}{l}0.088 * * \\
(0.036)\end{array}$ & $\begin{array}{l}0.182^{* *} \\
(0.083)\end{array}$ & $\begin{array}{l}0.169 * * \\
(0.086)\end{array}$ & $\begin{array}{l}0.168^{*} \\
(0.086)\end{array}$ \\
\hline Non - Innovator $\times 2010$ & $\begin{array}{l}-0.171^{* * *} \\
(0.033)\end{array}$ & $\begin{array}{l}-0.171^{* * *} \\
(0.033)\end{array}$ & $\begin{array}{l}-0.172^{* * * *} \\
(0.032)\end{array}$ & $\begin{array}{l}-0.237 * * * \\
(0.041)\end{array}$ & $\begin{array}{l}-0.239 * * * \\
(0.042)\end{array}$ & $\begin{array}{l}-0.239^{* * *} \\
(0.042)\end{array}$ \\
\hline Innovator $\times 2010$ & $\begin{array}{l}-0.204 * * * \\
(0.040)\end{array}$ & $\begin{array}{l}-0.205^{* * *} \\
(0.040)\end{array}$ & $\begin{array}{l}-0.208^{* * *} \\
(0.039)\end{array}$ & $\begin{array}{l}-0.234 * * * \\
(0.073)\end{array}$ & $\begin{array}{l}-0.236 * * * \\
(0.074)\end{array}$ & $\begin{array}{l}-0.236^{* * *} \\
(0.074)\end{array}$ \\
\hline $\begin{array}{l}\text { Founded between } 1997 \text { and } \\
\quad 2007\end{array}$ & $\begin{array}{r}0.040 \\
(0.026)\end{array}$ & $\begin{array}{r}0.040 \\
(0.026)\end{array}$ & $\begin{array}{r}0.039 \\
(0.026)\end{array}$ & $\begin{array}{r}0.101 \\
(0.075)\end{array}$ & $\begin{array}{r}0.102 \\
(0.080)\end{array}$ & $\begin{array}{r}0.101 \\
(0.078)\end{array}$ \\
\hline $\ln ($ Size $)$ & $\begin{array}{r}-0.030 \\
(0.029)\end{array}$ & $\begin{array}{r}-0.030 \\
(0.029)\end{array}$ & $\begin{array}{r}-0.037 \\
(0.026)\end{array}$ & $\begin{array}{r}-0.085 \\
(0.054)\end{array}$ & $\begin{array}{l}-0.091 * \\
(0.053)\end{array}$ & $\begin{array}{l}-0.093^{*} \\
(0.055)\end{array}$ \\
\hline $\ln (\text { Size })^{2}$ & $\begin{array}{c}0.006^{*} \\
(0.003)\end{array}$ & $\begin{array}{l}0.006^{* *} \\
(0.003)\end{array}$ & $\begin{array}{l}0.007 * * \\
(0.003)\end{array}$ & $\begin{array}{r}0.010 \\
(0.006)\end{array}$ & $\begin{array}{c}0.012^{*} \\
(0.006)\end{array}$ & $\begin{array}{l}0.012^{*} \\
(0.007)\end{array}$ \\
\hline Located in eastern Germany & & $\begin{array}{r}0.005 \\
(0.018)\end{array}$ & $\begin{array}{r}0.005 \\
(0.018)\end{array}$ & & $\begin{array}{l}0.104^{* *} \\
(0.050)\end{array}$ & $\begin{array}{l}0.105^{* *} \\
(0.051)\end{array}$ \\
\hline Active Exporter & & & $\begin{array}{r}0.022 \\
(0.022)\end{array}$ & & & $\begin{array}{r}0.006 \\
(0.053)\end{array}$ \\
\hline Industry Dummies & Yes & Yes & Yes & Yes & Yes & Yes \\
\hline $\mathrm{N}$ & 1188 & 1188 & 1188 & 410 & 410 & 410 \\
\hline Pseudo- $R^{2}$ & 0.137 & 0.137 & 0.138 & 0.149 & 0.158 & 0.158 \\
\hline
\end{tabular}

Cluster-robust standard errors in parentheses. Clustered at the industry level. Significance. Significance: * significant at the $10 \%$ level, $* *$ significant at the $5 \%$ level, $* * *$ significant at the $1 \%$ level.

\section{Comparison of revenue and investment growth}

\section{V.1 Empirical methodology}

To investigate hypothesis 2, we estimate a difference-in-differences equation. Innovative firms in our context are the treatment observations. Innovator $i$ assumes unit value in the case of firms which introduced a novelty to the market during the two years prior to 2007 and takes value zero for those firms which did not. The firms which introduced a novelty to the market (Innovator $\left._{i}=1\right)$ form our treatment group of firms. Those firms which did not carry out a product innovation are used as the control group.

The log change of revenues as growth rate of revenue is one of the dependent variables. Our intention is as follows: revenues reflect to what extent a firm is hit by the crisis due to reduced demand. In addition, sales represent the inflow of financial resources. Since we have no further 
information about the firms' internal financing resources, we take revenues as a proxy for the availability of internal means to finance investments. ${ }^{12}$

In the next step investment behavior over time is considered. We use the yearly log change in investments as the growth rate of investments. The line of reasoning with respect to hypothesis 2 is as follows: the economic downturn due to the financial crisis is likely to affect revenues of all firms. If the revenue of firms decreases it is in turn also probable that the firms' internal means to finance investments in physical assets will decrease. On the one hand, firms will to some degree reduce investment in general and on the other hand they will try to substitute the lacking internal financial resources with external funding. Section IV points to the conclusion that innovative firms have more difficulty receiving external funding. Then, even with a similar reduction in revenues, investment of the innovative firms will fall to a greater extent than investment by the non-innovative firms.

Next, we conduct a difference-in-differences analysis. The DID estimator compares both groups with each other before and after the crisis and would look like this:

$$
\begin{aligned}
& \tau_{D I D}=\left[E\left[\text { IR }_{i} \mid \text { Innovator }_{i}=1, \text { POST }_{i}=1\right]-E\left[\text { IR }_{i} \mid \text { Innovator }_{i}=1, \text { POST }_{i}=0\right]\right] \\
& -\left[E\left[I R_{i} \mid \text { Innovator }_{i}=0, P O S T_{i}=1\right]-E\left[I R_{i} \mid \text { Innovator }_{i}=0, P O S T_{i}=0\right]\right]
\end{aligned}
$$

Using the DID approach, we can control on the one hand for common effects like macroeconomic conditions and on the other hand for unobserved individual, time-invariant effects. We compare the effects on the innovators (our treatment group) with the non-innovators (our control group) for the years 2006 and 2009. Our difference-in-differences estimation is as follows:

$$
\begin{aligned}
I R_{i t} & =\beta_{0}+\beta_{1} * \text { POST }_{i}+\beta_{2} * \text { Innovator }_{i}+\tau_{D I D} * \text { Innovator }_{i} \times \text { POST }_{i} \\
& +\gamma * X_{i t}+\text { Industry }_{i}+\varepsilon_{i}
\end{aligned}
$$

We observe two outcomes which are described by $I R_{i t}$ i.e. Investment growth and Revenue growth. The variable $P O S T_{i}$ reflects the time effect and takes unit value if the time period after 2008/2009 is considered. We take the period 2008 as the start of the crisis due to the

\footnotetext{
${ }^{12}$ Hall et al. (1999) for instance show that sales lead to investment in physical assets and also investment in R\&D.
} 
fact that the banks were already experiencing their first problems in late $2007 .{ }^{13}$ The interaction Innovator $_{i} \times \mathrm{POST}_{i}$ identifies the treatment effect in the above regression framework.

\section{V.2 Difference-in-differences results}

This section presents the difference-in-differences results. Table 4 shows the descriptive statistics for the sample of firms observed in the years 2006 and 2009. We use 523 control firms and 217 treatment firms. About 10 percent of the control firms are younger than 10 years and the mean size is about 254 in both periods. About half of the control firms are located in the east and about two thirds are active exporters before and in the crisis. The treatment firms show almost similar values concerning age and location. Differences exist with respect to exporting behavior and firm size. Treatment firms export to a larger percentage and are on average larger. Both groups face a reduction in revenue and investment growth from the pre-crisis to the crisis period.

Table 4: Descriptive statistics for treatment and control group

\begin{tabular}{lrrrrrrrr}
\hline \multirow{2}{*}{ Variable } & \multicolumn{3}{c}{ Innovators } & & \multicolumn{3}{c}{ Non-Innovators } \\
\cline { 2 - 3 } & $\mathrm{N}$ & Pre-crisis & \multicolumn{1}{c}{ Crisis } & & $\mathrm{N}$ & Pre-crisis & \multicolumn{1}{c}{ Crisis } \\
\hline Revenue growth & 217 & 0.082 & -0.165 & 523 & 0.103 & -0.136 \\
Investment growth & 217 & 0.256 & -0.416 & 523 & 0.114 & -0.268 \\
Founded between 1997 and 2007 & 217 & 0.092 & 0.092 & 523 & 0.105 & 0.105 \\
Size & 217 & 773.018 & 797.600 & 523 & 254.918 & 254.478 \\
Located in eastern Germany & 217 & 0.493 & 0.488 & 523 & 0.482 & 0.482 \\
Active exporter & 217 & 0.783 & 0.811 & 523 & 0.639 & 0.654 \\
\hline
\end{tabular}

The results of the difference-in-differences estimations are presented in Table 5. We add several covariates and correct the standard errors according to the suggestion of Donald and Lang (2007) and Bertrand et al. (2004) by clustering at the industry level. The difference-in-differences estimates for the revenue growth are given in columns (1) to (3). Column (1) shows the estimate without controlling for anything other than industry affiliation. The coefficient of the interaction is negative and insignificant at conventional levels. In column (2), we present results with added covariates for age, size, geographical location and exporting behavior. These modifications do not affect the coefficient of the interaction variable with respect to its size and significance. Solely the coefficient of the variable indicating active exporters in column (2) is significant at the

${ }^{13}$ We follow works like Kipar (2011) and Puri et al. (2011). 
1 percent level. The results using firm fixed effects are shown in column (3). The coefficient of the interaction term changes slightly.

The difference-in-differences estimates support the first part of our hypothesis 2, which states that the crisis is expected to have similar effects on the revenues of both groups. The second part of Table 5 shows the outcome concerning investment growth. The results of the difference-indifferences estimations presented in column (4) show that compared to the non-innovators the innovators realize a significantly larger reduction in growth rates of investment. Column (5) displays the results of estimations with additional covariates. The picture remains essentially unchanged. According to these results the treated firms suffered much more from the crisis with respect to investment growth than the firms of the control group. The specification with firm fixed effects in column (6) shows a slightly decreased coefficient for the interaction term which remains significant at the 5 percent level.

Moreover, the results also remain similar if the variable size and/or age are specified differently. Restricting the sample to small firms equally leads to unaltered results. For hypothesis 2 to be confirmed we would need to estimate an insignificant difference-in-differences estimate for the revenue growth equation and a significant coefficient for the investment growth equation. This is exactly what we observe. 
Table 5: Estimation results for the investment behavior

\begin{tabular}{|c|c|c|c|c|c|c|}
\hline \multirow{2}{*}{ Variable } & \multicolumn{3}{|c|}{ Revenue growth } & \multicolumn{3}{|c|}{ Investment growth } \\
\hline & $(1)$ & $(2)$ & (3) & $(4)$ & (5) & (6) \\
\hline Innovator & $\begin{array}{r}-0.016 \\
(0.012)\end{array}$ & $\begin{array}{r}-0.007 \\
(0.012)\end{array}$ & & $\begin{array}{r}0.141 \\
(0.092)\end{array}$ & $\begin{array}{r}0.150 \\
(0.089)\end{array}$ & \\
\hline POST & $\begin{array}{l}-0.239 * * * \\
(0.042)\end{array}$ & $\begin{array}{l}-0.238^{* * *} \\
(0.042)\end{array}$ & $\begin{array}{l}-0.237 * * * \\
(0.059)\end{array}$ & $\begin{array}{l}-0.382^{* * *} \\
(0.081)\end{array}$ & $\begin{array}{l}-0.382^{* * *} \\
(0.080)\end{array}$ & $\begin{array}{l}-0.380^{* * *} \\
(0.116)\end{array}$ \\
\hline Innovator $\times$ POST & $\begin{array}{r}-0.008 \\
(0.026)\end{array}$ & $\begin{array}{l}-0.008 \\
(0.026)\end{array}$ & $\begin{array}{l}-0.016 \\
(0.036)\end{array}$ & $\begin{array}{l}-0.290 * * * \\
(0.095)\end{array}$ & $\begin{array}{l}-0.289 * * * \\
(0.095)\end{array}$ & $\begin{array}{l}-0.288^{* *} \\
(0.126)\end{array}$ \\
\hline $\begin{array}{l}\text { Founded between } 1997 \text { and } \\
2007\end{array}$ & & $\begin{array}{r}0.031 \\
(0.023)\end{array}$ & & & $\begin{array}{l}0.106 \\
(0.129)\end{array}$ & \\
\hline $\ln ($ Size $)$ & & $\begin{array}{r}0.017 \\
(0.028)\end{array}$ & $\begin{array}{r}0.201 \\
(0.461)\end{array}$ & & $\begin{array}{r}-0.036 \\
(0.139)\end{array}$ & $\begin{array}{r}0.961 \\
(1.414)\end{array}$ \\
\hline $\ln (S i z e)^{2}$ & & $\begin{array}{r}-0.003 \\
(0.003)\end{array}$ & $\begin{array}{r}0.005 \\
(0.045)\end{array}$ & & $\begin{array}{r}0.002 \\
(0.015)\end{array}$ & $\begin{array}{r}-0.134 \\
(0.148)\end{array}$ \\
\hline $\begin{array}{c}\text { Located in eastern } \\
\text { Germany }\end{array}$ & & $\begin{array}{r}0.004 \\
(0.013)\end{array}$ & & & $\begin{array}{r}0.042 \\
(0.085)\end{array}$ & \\
\hline Active exporter & & $\begin{array}{l}-0.028 * * * \\
(0.008)\end{array}$ & $\begin{array}{r}0.032 \\
(0.049)\end{array}$ & & $\begin{array}{r}-0.013 \\
(0.074)\end{array}$ & $\begin{array}{r}-0.020 \\
(0.261)\end{array}$ \\
\hline Constant & $\begin{array}{l}0.135^{* * *} \\
(0.021)\end{array}$ & $\begin{array}{r}0.122 \\
(0.075)\end{array}$ & $\begin{array}{r}-0.955 \\
(1.253)\end{array}$ & $\begin{array}{l}0.234^{* * *} \\
(0.042)\end{array}$ & $\begin{array}{r}0.317 \\
(0.311)\end{array}$ & $\begin{array}{r}-1.127 \\
(3.318)\end{array}$ \\
\hline $\begin{array}{l}\text { Firm fixed-effects } \\
\text { Industry Dummies }\end{array}$ & $\begin{array}{l}\text { No } \\
\text { Yes }\end{array}$ & $\begin{array}{l}\text { No } \\
\text { Yes }\end{array}$ & $\begin{array}{l}\text { Yes } \\
\text { No }\end{array}$ & $\begin{array}{l}\text { No } \\
\text { Yes }\end{array}$ & $\begin{array}{l}\text { No } \\
\text { Yes }\end{array}$ & $\begin{array}{l}\text { Yes } \\
\text { No }\end{array}$ \\
\hline $\mathrm{N}$ & 1480 & 1480 & 1480 & 1480 & 1480 & 1480 \\
\hline$R^{2}$ & 0.236 & 0.246 & 0.599 & 0.055 & 0.057 & 0.508 \\
\hline
\end{tabular}

Cluster-robust standard errors in parentheses. Clustered at the industry level. Significance. Significance: * significant at the $10 \%$ level, ${ }^{* *}$ significant at the $5 \%$ level, ${ }^{* * *}$ significant at the $1 \%$ level.

\section{Conclusion}

The impact of the financial crisis on banks is well known and frequently discussed. Because of the negative impact on banks and the associated restrictions for banks with respect to lending, it is likely that the financial crisis also had an impact on the real economy. Investment as an important source for growth, competitiveness of firms and welfare enhancement for consumers might be reduced. Our emphasis is the differentiation between innovating and non-innovating firms as there are theoretical arguments as to why innovative firms are more severely hit by the financial crisis.

To investigate this question we analyze on the one hand survey data, using information from the firms themselves to investigate how they evaluate the impact of the crisis. Firstly, innovative firms are generally more likely to be negatively affected by the crisis. Secondly, innovative firms more frequently reduce their investments due to the crisis. Hence, we find empirical support for 
our first hypothesis. According to our results innovative firms are more likely to be constrained with respect to financing their investment activities compared to non-innovative firms. These constraints lead innovative firms to reduce their investment activities.

Next, we use difference-in-differences estimations to determine the reasons for reduced investment during the crisis. We investigate the changes in growth rates of sales and investment. Sales are applied to investigate whether the crisis affected demand for output (and probably the availability of internal financial resources) of the innovative and non-innovative firms in the same way or differently. Difference-in-differences estimates point to the conclusion that the growth of revenues developed similarly for innovators and non-innovators. However, the impact of the crisis on investment by innovative firms is much stronger than on investment by other firms. Hence, while the impact during the crisis of the market on revenues is similar for both firm types, investment behavior is not. Innovative firms show much larger fluctuations in investment growth. Combining these results from the difference-in-differences estimations with the Probit estimations of the survey response, we conclude that the serious problems accessing external financing by innovative firms explains our observations.

An analysis of investment in physical assets is also of interest because they are correlated with $R \& D$ investments (Chiao 2001, 2002). It is likely that the R\&D investments of innovative firms also decreased significantly compared to the control firms due to the crisis. This hypothesis will be considered in more detail in the future.

Summarizing, innovative firms were hit more severely by the financial crisis, had more problems than others in accessing external finance and this had an impact on their expenditures for investment. Given the importance of investment for the implementation of the outcome of innovative projects and of innovation for the growth of economies one might wonder whether our results lead to policy implications. A possible measure would be a countercyclical public funding of innovative projects. In particular, if an economy suffers a very severe recession, additional help for innovators might be justifiable in order to substitute for the reduction in private financing. However for such a recommendation more research is needed. 


\section{References}

Archibugi, D., A. Filippetti and M. Frenz (2013a). Economic crisis and innovation: is destruction prevailing over accumulation? Research Policy, 42(2), 303-314.

Archibugi, D., A. Filippetti and M. Frenz (2013b). The impact of the economic crisis on innovation: Evidence from Europe. Technological Forecasting and Social Change, 80(7), 1247-1260.

Bertrand, M., E. Duflo, and S. Mullainathan (2004). How Much Should We Trust Differences-InDifferences Estimates? The Quarterly Journal of Economics, 119(1), 249-275.

Bond, S., D. Harhoff and J. Van Reenen (2005). Investment, R\&D, and financial constraints in Britain and Germany. Annales d'Economie et de Statistique 79/80, 433-460.

Brei, M. and A. Schclarek (2015). A theoretical model of bank lending: Does ownership matter in times of crisis? Journal of Banking \& Finance, 50, 298-307.

Campello, M., J. R. Graham and C. R. Harvey (2010). The real effects of financial constraints: Evidence from a financial crisis. Journal of Financial Economics, 97(3), 470-487.

Chiao, C. (2001). The relationship between R\&D and physical investment of firms in sciencebased industries. Applied Economics, 33(1), 23-35.

Chiao, C. (2002). Relationship between debt, R\&D and physical investment, evidence from US firm-level data. Applied Financial Economics, 12(2), 105-121.

Cowling, M., W. Liu and A. Ledger (2012). Small business financing in the UK before and during the current financial crisis. International Small Business Journal, 30(7), 778800.

Czarnitzki, D. and H. Hottenrott (2011a). Financial Constraints: Routine Versus Cutting Edge R\&D Investment. Journal of Economics and Management Strategy, 20(1), 121-157.

Czarnitzki, D. and H. Hottenrott (2011b). R\&D Investment and Financing Constraints of Small and Medium-Sized Firms. Small Business Economics, 36(1), 65-83.

David, P.A., B.H. Hall and A.A. Toole (2000). Is Public R\&D a Complement or Substitute for Private R\&D? A Review of the Econometric Evidence. Research Policy, 29, 497529.

Donald S. G. and K. Lang (2007). Inference with Difference-in-Differences and Other Panel Data. The Review of Economics and Statistics, 89(2), 221-233.

Duchin, R., O. Ozbas, B. A. Sensoy (2010). Costly external finance, corporate investment, and the subprime mortgage credit crisis. Journal of Financial Economics, 97(3), 418435.

Fazzari, S.M., R.G. Hubbard, B.C. Petersen (1988). Financing constraints and corporate investment. Brookings Papers on Economic Activity, 1, 141-206.

Filippetti, A. and D. Archibugi (2011). Innovation in times of crisis: national systems of innovation, structure, and demand. Research Policy, 40(2), 179-192. 
Hall, B. H. (1992). Investment and research and development at the firm level: does the resource of financing matter? NBER Working Paper No. 4096.

Hall, B. H., Branstetter, L., Crépon, B., Mairesse, J. (1999). Does cash flow cause investments and R\&D: An exploration using panel data for French, Japanese, and United States firms in the scientific sector, In: Audretsch, D. and A.R. Thurik (Eds.), Innovation, Industry Evolution and Employment, Cambridge University Press, UK: Cambridge, 129-156.

Hall, B. H. (2002). The Financing of Research and Development. Oxford Review of Economic Policy, 18(1), 35-51.

Harhoff, D. (1998) Are There Financing Constraints for R\&D and Investment in German Manufacturing Firms? Annales d’Économie et de Statistique, 49/50, 421-456.

Himmelberg, C. P. and B. C. Petersen (1994). R\&D and Internal Finance: A Panel Study of Small Firms in High-Tech Industries. The Review of Economics and Statistics, 76(1), 38-51.

Holmstrom, B. and J. Tirole (1997). Financial intermediation, loanable funds, and the real sector. The Quarterly Journal of Economics, 112(3), 663-691.

Ivashina, V. and D. Scharfstein (2010). Bank lending during the financial crisis of 2008. Journal of Financial Economics, 97(3), 319-338.

Iyer, R., J.-L. Peydró, S. da-Rocha-Lopes and A. Schoar (2014). Interbank Liquidity Crunch and the Firm Credit Crunch: Evidence from the 2007-2009 Crisis. Review of Financial Studies, 27(1), 347-372.

Kipar, S. (2011). Kreditvergabe und Innovationsaktivität in der Finanzkrise. Vierteljahrshefte zur Wirtschaftsforschung, 80(3), 111-129.

Lee, S., H. Sameen and M. Cowling (2015). Access to finance for innovative SMEs since the financial crisis. Research Policy, 44(2), 370-380.

Mina, A., H. Lahr and A. Hughes (2013). The demand and supply of external finance for innovative firms. Industrial and Corporate Change, 22(4), 869-901.

Mohnen, P., F. Palm, S. Loeff and A. Tiwari (2008). Financial Constraints and Other Obstacles: Are They a Threat to Innovation Activity? De Economist, 156(2), 201-214.

Myers, S. S. and N. S. Majluf (1984). Corporate Financing and Investment Decisions when Firms have Information that Investors do not have. Journal of Financial Economics, 13(2), 187-221.

Paunov, C. (2012). The global crisis and firms' investments in innovation. Research Policy, 41(1), 24-35.

Puhani, P. A. (2012). The Treatment Effect, the Cross Difference, and the Interaction Term in Nonlinear “Difference-in-Differences” Models. Economics Letters, 115(1), 85-87. 
Puri, M., J. Rocholl and S. Steffen (2011). Global retail lending in the aftermath of the US financial crisis: Distinguishing between supply and demand effects. Journal of Financial Economics, 100(3), 556-578.

Savignac, F. (2008). Impact of Financial Constraints on Innovation: What Can Be Learned from a Direct Measure? Economics of Innovation and New Technology, 17(6), 553-569.

Stiglitz, J. and A. Weiss (1981). Credit rationing in markets with imperfect information. American Economic Review, 71(3), 393-410

Tiwari, A., P. Mohnen, F. Palm, and S. Schim van der Loeff (2007). Financial Constraint and R\&D Investment: Evidence from CIS, UNU-MERIT Working Paper Series 011, Maastricht.

Whited, T.M. (1992). Debt, Liquidity Constraints, and Corporate Investment: Evidence from Panel Data. The Journal of Finance, 47(4), 1425-1460. 